\title{
Hubungan Pengetahuan, Sikap dengan Tindakan Perawat dalam Pemilahan Limbah Padat Medis dan Limbah Padat Non Medis
}

\section{Bambang ${ }^{1}$, Setiawan'2 Marlik $^{3}$}

1. Poltekkes Kemenkes Surabaya,

Email: bambangbaihaqi@gmail.com

2. Poltekkes Kemenkes Surabaya,

Email: setiawan.jemblung@yahoo.com

3. Poltekkes Kemenkes Surabaya,

Email: marlik2503@gmail.com

\section{ABSTRACT}

Medical Waste solid is solid waste that consist of waste infeksius, pathology waste, sharp object waste, pharmacy waste, waste sitotoksis, chemical disposal, radioactive waste, waste container and waste with high heavy metal content. Solid Waste non medical is solid waste that produced by from activity in hospital outside medical that indigenous to kitchen, office, garden, and hall. Target at research this is the relation analysis between knowledge and nurse understanding hit sorting medical garbage. and garbage non medical in IGD RSUD Dr. Soetomo Surabaya. Type from research is analytic research by using design wake up research that is a research design that used by to study correlation between variable dependen and independent variable. Population in this research 34 nurse responders in Installation Emergency Departments. This Research is executed during the month of January-February 2019. This Research uses intake technique sampel nonprobability sampling. Data collecting Method uses admission filling quesioner.

Keywords: Knowledge, Attitude, Action 


\section{ABSTRAK}

Limbah medis padat adalah limbah padat yang terdiri dari limbah infeksius, limbah patologi, limbah benda tajam, limbah farmasi, limbah sitotoksis, limbah kimiawi, limbah radioaktif, limbah container bertekanan dan limbah dengan kandungan logam berat yang tinggi. Limbah padat non medis adalah limbah padat yang dihasilkan dari kegiatan dirumah sakit di luar medis yang berasal dari dapur, perkantoran, taman, dan halaman. Tujuan pada penelitian ini adalah menganalisis hubungan antara pengetahuan dan pemahaman perawat mengenai pemilahan sampah medis.dan sampah non medis di IGD RSUD Dr. Soetomo Surabaya. Jenis dari penelitian adalah penelitian analitik dengan menggunakan rancang bangun penelitian yaitu suatu desain penelitian yang digunakan untuk mempelajari korelasi antara variabel dependen dan variabel independen. Populasi dalam penelitian ini sebanyak 34 responden perawat di Instalasi Gawat Darurat RSUD Dr. Soetomo Surabaya. Penelitian ini dilaksanakan selama bulan Januari-Februari 2019. Penelitian ini menggunakan teknik pengambilan sampel nonprobability sampling. Metode pengumpulan data menggunakan pengisian kuesioner.

Kata Kunci: Pengetahuan, Sikap, Tindakan 


\section{Pendahuluan}

Limbah padat rumah sakit adalah semua limbah rumah sakit yang berbentuk padat sebagai akibat kegiatan rumah sakit yang terdiri dari limbah medis padat dan non medis. Penanganan limbah medis yang tidak dikelola dengan baik dapat menyebabkan infeksinosokomial.Infeksi

nosokomial (IN) disebut juga Hospital Acquired Infection atau Hospital Associated Infection adalah infeksi yang terjadi di rumah sakit, atau disebabkan oleh kuman yang didapat selama berada di rumah sakit.

Berdasarkan survey pendahuluan yang telah dilakukan oleh peneliti pada bulan April sampai Juni di Instalasi Sanitasi Lingkungan RSUD Dr. Soetomo Surabaya, peneliti melakukan wawancara dengan tenaga medis yaitu yang bertugas di IGD RSUD Dr. Soetomo, sering ditemukan tercarnpurnya antara limbah padat medis dengan limbah padat non medis. Ini dianggap telah melanggar Keputusan Menteri Kesehatan Republik Indonesia Nomor 1204/Menkes/SK/X/2004 bahwa pewadahan limbah padat non medis harus dipisahkan dari limbah padat medis dan ditampung dalam kantong plastik warna hitam dan di setiap sumber penghasil limbah medis harus tersedia tempat pewadahan yang terpisah dengan limbah padat non medis.Dan dari hasil pengamatan peneliti secara langsung, jenis kelamin, umur, masa kerja dan tingkat pendidikan tenaga medis juga menjadi faktor tercapainya pengelolaan limbah padat yang sesuai dengan aturan yang berlaku.

Dengan adanya masalah pada pemilahan limbah padat medis dengan limbah padat non medis tersebut, peneliti melakukan penelitian Skripsi dengan judul "Hubungan Pengetahuan, Sikap Dengan Tindakan Perawat Dalam Pemilahan Limbah Padat Medis Dan Limbah Padat Non Medis (Studi di Instalasi Gawat Darurat RSUD Dr. Soetomo Surabaya Tahun 2019)"

\section{Metode}

Penelitian ini termasuk dalam jenis penelitian analitik dengan menggunakan rancang bangun penelitian yaitu suatu desain penelitian yang digunakan untuk mempelajari korelasi antara variabel dependen dan variabel independen, Lokasi penelitian adalah di IGD RSUD dr. Soetomo Surabaya, dengan pertimbangan bahwa IGD merupakan salah satu tempat di RSUD Dr. Soetomo yang memiliki mobilitas cukup tinggi, Populasi dalam penelitian ini adalah 34 Perawat IGD RSUD Dr. Soetomo, Mengingat jumlah populasi yang relatif sedikit yakni 34 orang perawat, maka semua perawat yang bekerja akan diteliti semuanya sebanyak 34 Perawat IGD RSUD Dr. Soetomo yang akan diteliti dengan cara wawancara berdasarkan kuisioner yang telah disiapkan. 


\section{Hasil Penelitian}

1. Jenis Kelamin

Tabel 5.8

Hubungan Jenis Kelamin dengan Tingkat Pengetahuan Tentang pemilahan limbah medis dan limbah non medis Di IGD RSUD

Dr. Soetomo Tahun 2019

\section{Tingkat}

Pengetahuan

\begin{tabular}{|c|c|c|c|c|c|c|c|c|}
\hline No. & $\begin{array}{c}\text { Jenis } \\
\text { Kelamin }\end{array}$ & & Baik & & $\begin{array}{l}\text { urang } \\
\text { Baik }\end{array}$ & & otal & $\mathbf{P}$ \\
\hline 1. & Laki-laki & $\begin{array}{l}1 \\
9\end{array}$ & $\begin{array}{c}55,88 \\
\%\end{array}$ & 1 & $2,94 \%$ & 20 & $\begin{array}{c}58,82 \\
\%\end{array}$ & \\
\hline 2 . & $\begin{array}{l}\text { Perempu } \\
\text { an }\end{array}$ & 7 & $\begin{array}{c}20,58 \\
\%\end{array}$ & 7 & $\begin{array}{c}20,58 \\
\%\end{array}$ & 14 & $\begin{array}{c}41,17 \\
\%\end{array}$ & \\
\hline & Total & $\begin{array}{l}2 \\
6\end{array}$ & $\begin{array}{c}76,47 \\
\%\end{array}$ & 8 & $\begin{array}{c}23,53 \\
\%\end{array}$ & 34 & $100 \%$ & $\begin{array}{c}0,00 \\
4\end{array}$ \\
\hline
\end{tabular}

2. Umur

Tabel 5.9

Hubungan Umur dengan Tingkat Pengetahuan Tentang pemilahan limbah medis dan limbah non medis Di IGD RSUD Dr. Soetomo Tahun 2019

\begin{tabular}{|c|c|c|c|c|c|c|c|c|}
\hline \multicolumn{9}{|c|}{ Tingkat Pengetahuan } \\
\hline No & Umur & & Baik & & $\begin{array}{l}\text { urang } \\
\text { Baik }\end{array}$ & & otal & $\mathbf{P}$ \\
\hline 1. & $\begin{array}{l}<25 \\
\text { Tahun }\end{array}$ & 1 & $\begin{array}{c}2,94 \\
\%\end{array}$ & 5 & $14,7 \%$ & 6 & $\begin{array}{c}17,65 \\
\%\end{array}$ & \\
\hline 2. & $\begin{array}{l}25- \\
45 \text { Tahun }\end{array}$ & $\begin{array}{l}1 \\
5\end{array}$ & $\begin{array}{c}44,11 \\
\%\end{array}$ & 3 & $8,82 \%$ & $\begin{array}{l}1 \\
8\end{array}$ & $\begin{array}{c}52,94 \\
\%\end{array}$ & \\
\hline 3. & $\begin{array}{l}>45 \\
\text { Tahun }\end{array}$ & $\begin{array}{l}1 \\
0\end{array}$ & $\begin{array}{c}29,40 \\
\%\end{array}$ & 0 & $0,0 \%$ & $\begin{array}{l}1 \\
0\end{array}$ & $\begin{array}{c}29,40 \\
\%\end{array}$ & \\
\hline & Total & $\begin{array}{l}2 \\
6 \\
\end{array}$ & $\begin{array}{c}76,47 \\
\%\end{array}$ & 8 & $\begin{array}{c}23,53 \\
\%\end{array}$ & $\begin{array}{l}3 \\
4\end{array}$ & $100 \%$ & $\begin{array}{l}0,0 \\
00\end{array}$ \\
\hline
\end{tabular}


3. MasaKerja

Tabel 5.10

Hubungan Masa Kerja dengan Tingkat Pengetahuan Tentang pemilahan limbah medis dan limbah non medis Di IGD RSUD

Dr. Soetomo

Tahun 2019

\section{Tingkat Pengetahuan}

\begin{tabular}{|c|c|c|c|c|c|c|c|c|}
\hline No & $\begin{array}{l}\text { Masa } \\
\text { Kerja }\end{array}$ & & Baik & & $\begin{array}{l}\text { urang } \\
\text { Baik }\end{array}$ & & otal & $\mathbf{P}$ \\
\hline 1. & $\begin{array}{l}<\quad 5 \\
\text { Tahu } \\
\mathrm{n}\end{array}$ & 1 & $2,94 \%$ & 4 & $\begin{array}{c}11,76 \\
\%\end{array}$ & 5 & $\begin{array}{c}14,70 \\
\%\end{array}$ & \\
\hline 2. & $\begin{array}{l}5-10 \\
\text { Tahu } \\
n\end{array}$ & $\begin{array}{l}1 \\
1\end{array}$ & $\begin{array}{c}32,35 \\
\%\end{array}$ & 4 & $\begin{array}{c}11,76 \\
\%\end{array}$ & $\begin{array}{l}1 \\
5\end{array}$ & $\begin{array}{c}44,11 \\
\%\end{array}$ & \\
\hline 3. & $\begin{array}{l}>\quad 10 \\
\text { Tahu } \\
n\end{array}$ & $\begin{array}{l}1 \\
4\end{array}$ & $\begin{array}{c}41,17 \\
\%\end{array}$ & 0 & $0 \%$ & $\begin{array}{l}1 \\
4\end{array}$ & $\begin{array}{c}41,17 \\
\%\end{array}$ & \\
\hline & Cotal & $\begin{array}{l}2 \\
6 \\
\end{array}$ & $\begin{array}{c}76,47 \\
\% \\
\end{array}$ & 8 & $\begin{array}{c}23,53 \\
\%\end{array}$ & $\begin{array}{l}3 \\
4 \\
\end{array}$ & 100 & $\begin{array}{c}0,00 \\
1 \\
\end{array}$ \\
\hline & & & Chi-Sq & & $=13,2$ & & & \\
\hline
\end{tabular}

4. Tingkat Pendidikan

Tabel 5.11

Hubungan Tingkat Pendidikan dengan Pengetahuan

Tentang pemilahan limbah medis dan limbah non medis Di

IGD RSUD Dr. Soetomo

Tahun 2019

\section{Tingkat}

Pengetahuan

\begin{tabular}{|c|c|c|c|c|c|c|c|c|}
\hline $\begin{array}{c}\text { No } \\
\text {. }\end{array}$ & $\begin{array}{c}\text { Pendidik } \\
\text { an }\end{array}$ & & Baik & & $\begin{array}{l}\text { drang } \\
\text { Baik }\end{array}$ & & otal & $\mathbf{P}$ \\
\hline 1. & SMA & 1 & $\begin{array}{c}2,94 \\
\%\end{array}$ & 5 & $\begin{array}{c}14,70 \\
\%\end{array}$ & 6 & $\begin{array}{c}17,64 \\
\%\end{array}$ & \\
\hline 2. & DIPLOM & 1 & 44,11 & 3 & 8,82 & 1 & 52,94 & \\
\hline
\end{tabular}


Bambang: Hubungan Pengetahuan

\begin{tabular}{llcccccc} 
A & 5 & $\%$ & & $\%$ & 8 & $\%$ & \\
\hline 3. SARJANA & 1 & 29,40 & 0 & $0 \%$ & 1 & 29,40 & \\
& 0 & $\%$ & & 0 & $\%$ & \\
\hline \multirow{2}{*}{ Total } & 2 & 76,47 & 8 & 23,53 & 3 & $100 \%$ & 0,00 \\
& 6 & $\%$ & $\%$ & 4 & & 0 \\
\hline \multicolumn{7}{c}{ Chi-Square $=15,474$} \\
\hline
\end{tabular}

5. Tingkat Pengetahuan

Tabel 5.5

Distribusi Frekuensi Tingkat Pengetahuan Perawat Tentang Pemilahan Limbah Medis Dan Non Medis di IGD RSUD Dr. Soetomo Tahun2019

\begin{tabular}{clcc}
\hline No & Pengetahuan & Frekuensi & Persentase \\
\hline 1 & Kurang Baik & 8 & $23,5 \%$ \\
2 & Baik & 26 & $76,5 \%$ \\
\hline Total & & 34 & 100 \\
\hline
\end{tabular}

6. Sikap

Tabel 5.6

Distribusi Frekuensi SikapPerawat Tentang Pemilahan Limbah Medis Dan Non Medis di IGD RSUD Dr. Soetomo Tahun2019

\begin{tabular}{clcc}
\hline No & Sikap & Frekuensi & Persentase \\
\hline 1 & Kurang Baik & 5 & 14.7 \\
2 & Baik & 29 & 85.3 \\
\hline Total & & 34 & 100 \\
\hline
\end{tabular}

7. Tindakan

Tabel 5.7

Distribusi Frekuensi TindakanPerawat Tentang Pemilahan Limbah Medis Dan Non Medis di IGD RSUD Dr. Soetomo Tahun2019

\begin{tabular}{clcc}
\hline No & \multicolumn{1}{c}{ Tindakan } & Frekuensi & Persentase \\
\hline 1 & Kurang Baik & 10 & 29,4 \\
2 & Baik & 24 & 70,6 \\
\hline
\end{tabular}




\begin{tabular}{ll}
\hline Total & \\
\hline 8. Hubungan & Tingkat \\
Pengetahuan & Dengan \\
Sikap Perawat, & sebagai \\
berikut; &
\end{tabular}

Tabel 5.12

Hubungan Tingkat Pengetahuan dengan Sikap Perawat Tentang pemilahan limbah medis dan limbah non medis

Di IGD RSUD Dr. Soetomo Tahun 2019

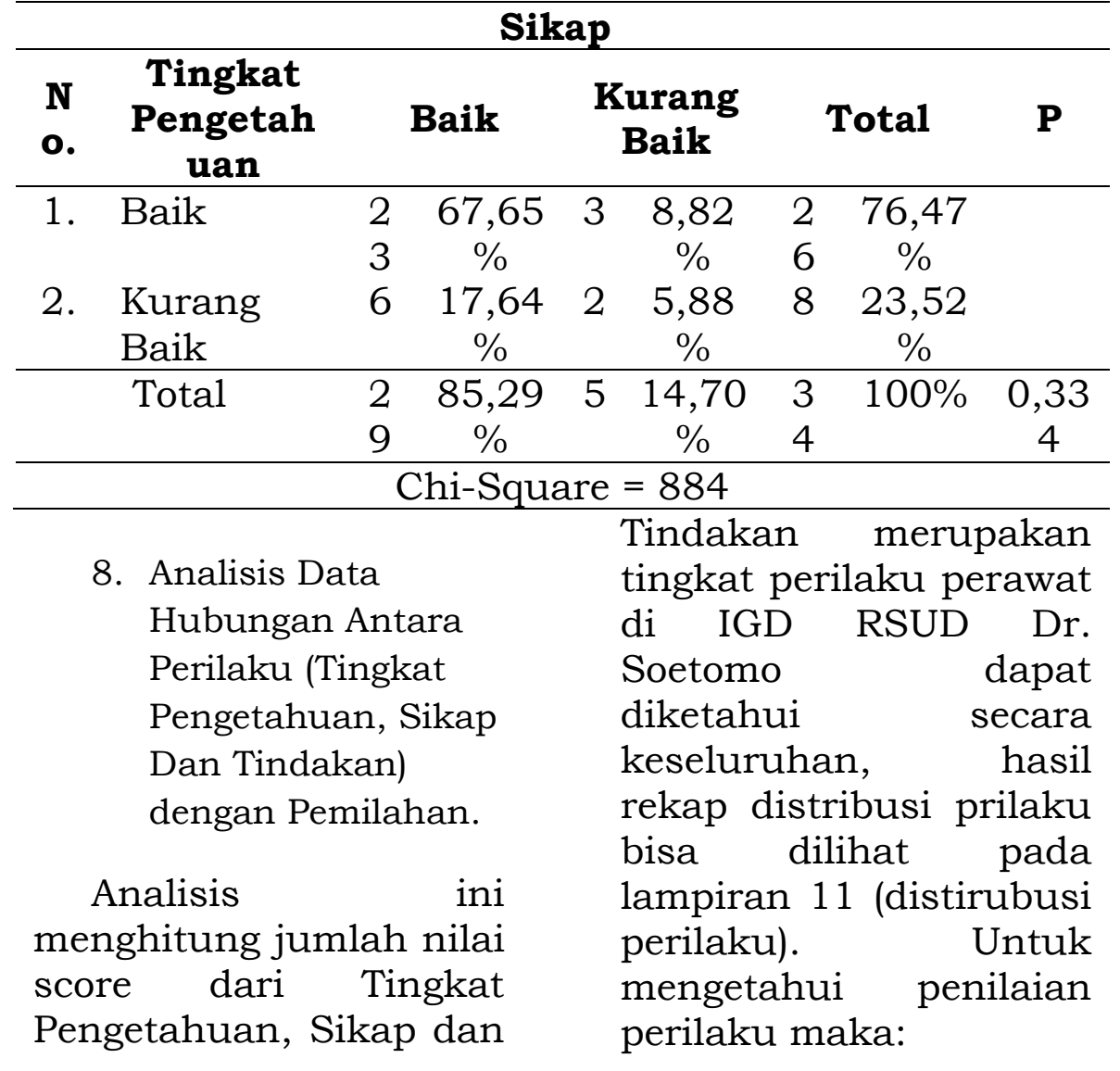


Bambang: Hubungan Pengetahuan

Perilaku $=$ Tingkat

Pengetahuan + Sikap +

Tindakan

Mengetahui

Tingkat

Perilaku

Penilaian jawaban

pertanyaan

nomor $1 \mathrm{~s} / \mathrm{d} 10$ yaitu :

Perhitungan

Nilai maksimum $=\sum$ soal

Tingkat Pengetahuan +

$\sum$ Sikap $+\sum$ Tindakan

$=20+20+20=20$
Nilai maksimum $=\sum$ soal Tingkat Pengetahuan $+\quad \sum$ Sikap + $\sum$ Tindakan

$=10+10+10$

$=30$

Kelas Interval $=2$ (baik, kurang

baik)

Jarak Interval

$=\frac{\text { Nilai maksimal-Nilai minimun }}{\text { Kelas Interval }}$

$=(60-30) / 2=30 / 2=15$

Klasifikasi penilaian

Tabel 5.13

Klasifikasi Tingkat Perilaku

Berdasarkan Jumlah Skor Jawaban Tingkat Pengetahuan, Sikap, Tindakan

\begin{tabular}{|c|c|c|l|}
\hline No. & Skore & Persen & \multicolumn{1}{c|}{ Klasifikasi } \\
\hline 1. & $45,1-60$ & $51-100 \%$ & $15 \geq=$ Baik \\
\hline 2. & $30-45,0$ & $0-50 \%$ & $\begin{array}{l}15<=\text { Kurang } \\
\text { baik }\end{array}$ \\
\hline
\end{tabular}

Variabel Sikap (Skala Likert)

Untuk hubungan

dengan pemilahan, perlu dilakukan

Crosstabulation analisi tabulasi silang, berikut adalah hasil uji tabulasi silang:

Tabel 5.14

Hubungan Tingkat Perilaku Dengan Pemilahan

Limbah medis dan limbah non medis

Di IGD RSUD Dr. Soetomo Tahun 2019

\section{DO (Pemilahan}

Limbah)

\begin{tabular}{cccccccc}
\hline No & $\begin{array}{c}\text { Perilak } \\
\text { u }\end{array}$ & \multicolumn{2}{c}{$\begin{array}{c}\text { Bisa } \\
\text { Memilah }\end{array}$} & \multicolumn{2}{c}{$\begin{array}{c}\text { Kurang } \\
\text { Bisa } \\
\text { Memilah }\end{array}$} & Total & P \\
\hline 1. & Baik & 2 & 85,3 & 3 & $8,8 \%$ & 3 & 94,1 \\
& & 9 & $\%$ & & & 2 & $\%$ \\
2. & Kurang & 0 & $0,0 \%$ & 2 & $5,9 \%$ & 2 & $5,9 \%$ \\
\hline
\end{tabular}


Baik

Bambang: Hubungan Pengetahuan

\begin{tabular}{cccccccc} 
Total & 2 & 85,3 & 5 & 14,70 & 3 & $100 \%$ & 0,00 \\
& 9 & $\%$ & $\%$ & 4 & & 0 \\
\multicolumn{6}{c}{ Chi-Square $=12.325$} \\
$c$
\end{tabular}

\section{Pembahasan}

\section{Jenis Kelamin}

Berdasarkan hasil penelitian di Instalasi Rawat Darurat RSUD Dr. Soetomo yang diteliti 34 responden dapat diketahui bahwa jumlah responden laki-laki lebih dominan di bandingkan jumlah responden perempuan yaitu sebesar 20 perawat dengan presentase 68\%. Dan nilai $p$-value yang diketahui sebesar $0,001 \quad$ yang menunjukkan bahwa adanya hubungan mengenai jenis kelamin dengan penerapan.

Hasil ini sesuai dengan teori yang di nyatakan Robbins (2006) bahwa, tidak ada perbedaan yang konsisten antara lakilaki dan perempuan dalam kemampuan memecahkan masalah, keterampilan analisis dorongan kompetitif, motivasi, sosiabilitas, atau kemampuan belajar.Namun studistudi psikologi telah menemukan bahwa perempuan lebih bersedia untuk mematuhi wewenang dan laki-laki lebih agresif dan lebih besar kemungkinannya daripada perempuan dalam memiliki penghargaan untuk sukses.

\section{Umur}

Berdasarkan hasil penelitian di Instalasi Rawat Darurat RSUD Dr. Soetomo yang diteliti 34 responden dapat diketahui bahwa jumlah responden sebagian besar berusia diantara 25-45 tahun yaitu sebesar 18 perawat dengan presentase $52,9 \%$. Dan nilai $P$ yang diketahui sebesar $0,000 \quad$ yang menunjukkan bahwa adanya hubungan mengenai umur dengan tingkat pengetahuan. 
Hasil ini sesuai dengan teori yang di nyatakanYulianti

(2003) bahwa, usia berpengaruh pada keaktifan seseorang untuk berpartisipasi, dalam hal ini golongan tua yang dianggap lebih berpengalaman atau senior, akan lebih banyak memberikan pendapat dalam hal menetapkan

keputusan.

\section{Masa Kerja}

Berdasarkan hasil penelitian di Instalasi Rawat Darurat RSUD Dr. Soetomo yang diteliti dari 34 responden dapat diketahui bahwa jumlah responden yang mendominasi masa kerjanya sudah $>10$ tahun yaitu sebaayak 14 orang dengan presentase 41,2 \%. Dan nilai yang diketahui sebesar $0,001 \quad$ yang menunjukkan bahwa adanya hubungan mengenai masa kerja dengan penerapan.

Hasil ini sesuai dengan teori yang di nyatakan Kreitner dan Kinicki (2004) bahwa, masa kerja yang lama akan cenderung
Bambang: Hubungan Pengetahuan membuat seseorang pegawai lebih merasa betah dalam suatu organisasi, hal ini disebabkan

diantaranya karena telah beradaptasi dengan lingkungannya yang cukup lama sehingga seorang pegawai akan merasa nyaman dengan pekerjannya. Penyebab lain juga dikarenakan adanya kebijakan dari instansi perusahaan mengenai jaminan hidup di hari tua.

\section{Tingkat Pendidikan}

Berdasarkan hasil penelitian di Instalasi Rawat Darurat RSUD Dr. Soetomo yang diteliti dari 34 Responden yang dominan adalah jenjang pendidikannya Diploma yaitu sebanyak 18 orang dengan presentase 52,9 \%. Dan nilai $P$ yang diketahui sebesar $0,000 \quad$ yang menunjukkan bahwa adanya hubungan mengenai tingkat pendidikan dengan penerapan pemilahan

Hasil ini sesuai dengan teori yang di nyatakan Notoatmodjo (2007) bahwa, 
pendidikan sekarang menentukan luasnya pengetahuan seseorang dimana orang yang berpendidikan dan bekerja dalam bidang kesehatan dan keselamatan kerja dapat memberikan landasan yang mendasar sehingga memerlukan partisipasi secara efektif dalam menemukan sendiri pemecahan masalah ditempat kerja (Notoatmodjo, 2007).

5. Tingkat Pengetahuan

Berdasarkan hasil penelitian di Instalasi Rawat Darurat RSUD Dr. Soetomo dapat diketahui yang tingkat pengetahuannya dengan kategori baik sebesar 26 orang dengan presentase 76.5\%. Maka dari hasil diatas seharusnya perawat di IRD RSUD Dr. Soetomo seharusnya sudah dapat memilah sampah medis dan sampah non medis dengan benar. Pengetahuan dapat ditingkatkan dengan cara mengikuti sosialisasi yang
Bambang: Hubungan Pengetahuan temanya mengenai pemilahan sampah medis dan sampah non medis.

Suriasumantri (2003) bahwa, segenap apa yang diketahui manusia tentang suatu objek tertentu termasuk didalamnya ilmu yang akan memperkaya khasanah mentalnya baik secara langsung ataupun tidak langsung.

Pengetahuan diartikan juga sebagai suatu kumpulan berbagai macam pengalaman, nilai-nilai dan informasi yang saling berkaitan.Di dalamnya terkandung juga berbagai gagasan para ahli dan informasi baru yang berkaitan dengan objek pengetahuan tersebut. Dalam kelangsungannya pengetahuan tersebut tidak hanya disimpan sebagai ingatan, tetapi juga dilibatkan dalam berbagai proses terapan.

\section{Sikap}

Berdasarkan hasil penelitian di Instalasi Rawat Darurat RSUD 
Dr. Soetomo yang tingkat

pemahamannya

dengan kategori baik

sebesar 29 orang

dengan presentase

85,3\%. Dari hasil

diatas dapat diketahui bahwa perawat di IRD RSUD Dr. Soetomo sebagian dari jumlah responden 34 ada beberapa orang yang tingkat sikap pemahamannya baik. Peningkatan

pemahaman perawat dapat dilakukan dengan cara mengadakan studi kasus untuk setiap unit, bisa di koordinator oleh setiap kepala ruangan masing - masing unit. Senja (2008) pemahaman berasal dari kata paham yang mempunyai arti benar, sedangkan

pemahaman

merupakan proses perbuatan cara memahami. Dapat juga diartikan sebagai suatu proses, cara memahami cara mempelajari baik baik supaya paham dan pengetahuan banyak.

\section{Tindakan}

Bambang: Hubungan Pengetahuan

Berdasarkan hasil penelitian di Instalasi Rawat Darurat RSUD Dr. Soetomo yang tingkat

pemahamannya dengan kategori cukup baik sebesar 24 orang dengan presentase $70,6 \%$. Dari hasil diatas dapat diketahui bahwa perawat di IRD RSUD Dr. Soetomo sebagian dari jumlah responden 34 ada beberapa orang yang tingkat penerapannya cukup dan ada pula yang tingkat penerapannya baik.

$\mathrm{AH}$ (2005) penerapan adalah sebuah tindakan yang dilakukan baik secara individu maupun kelompok dengan maksud untuk mencapai tujuan yang telah dirumuskan. Dapat juga diartikan sebuah bentuj dari langkah nyata dari sebuah penghayatan atau perencanaan yang lebih diyakini.

8. Hubungan Tingkat Pengetahuan, sikap dan tindakan perawat terhadap Pemilahan Limbah Padat Medis Dan Limbah Padat Non Medis 
Berdasarkan hasil penelitian pemilahan limbah padat medis dan limbah padat non medis di Instalasi Rawat Darurat RSUD Dr. Soetomo yang tingkat hubungan dijelaskan sebagai berikut:

- Berdasarkan Tabel 5.12 diperoleh hasil yang tingkat pengetahuannya dalam kategori baik yang pada sikap penilaian baik sebesar 23 perawat dengan presentase $67,65 \%$ nilai $\mathrm{P}$ value $=0,334$ yang menunjukkan tidak adanya hubungan mengenai tingkat pengetahuan

dengan sikap perawat.

- Berdasarkan Tabel 5.13 diperoleh hasil yang tingkat pengetahuannya dalam kategori baik yang pada tindakan penilaian

baik sebesar 21 perawat dengan presentase $61,76 \%$ nilai $\mathrm{P}$ value $=0,031$ yang menunjukkan adanya hubungan mengenai tingkat pengetahuan
Bambang: Hubungan Pengetahuan dengan tindakan perawat.

- Berdasarkan Tabe1 5.14 diperoleh hasil yang sikap dalam kategori baik yang pada tindakan penilaian baik sebesar 23 perawat dengan presentase $67,65 \%$ nilai Pvalue $=0,019$ yang menunjukkan adanya hubungan mengenai tingkat pengetahuan dengan tindakan perawat.

Jumlah skor Pengetahuan, sikap dan tindakan, secara umum sikap kategori baik lebih dominan, dengan kategori baik sebesar 29 orang dengan presentase $\quad 85,29 \%$. Dari hasil diatas dapat diketahui bahwa perawat di IRD RSUD Dr. Soetomo sebagian dari jumlah responden 34 ada beberapa orang yang tingkat penerapannya baik.

\section{Simpulan}

Hasil nilai tingkat pengetahuan perawat dengan tindakan perawat dan hasil nilai sikap perawat dengan tindakan perawat dalam 
pemilahan limbah padat medis dan limbah padat non medis di IGD RSUD Dr. Soetomo dalam penelitian ini, dapat disimpulkan bahwa ada hubungan, Hasil nilai tingkat pengetahuan dengan sikap perawat dalam pemilahan limbah padat medis dan limbah padat non medis di IGD RSUD Dr. Soetomo dalam penelitian ini, dapat disimpulkan bahwa tidak ada hubungan, Dari hasil analisis bahwa pengetahuan, sikap dan tindakan dalam pemilahan limbah padat medis dan limbah padat non medis di IGD RSUD Dr. Soetomo, terdapat hubungan yang signifikan, Dari analisis perilaku perawat terhadap pemilahan limbah padat non medis di IGD RSUD Dr. Soetomo terdapat hubungan yang signifikan. Dalam analisis tabulasi silang antara perilaku dan DO pemilahan terdapat 2 perawat dengan perilaku kurang baik dan kurang bisa memilah, maka dengan bantuan rekan perawat
Bambang: Hubungan Pengetahuan

dan pengamat memberikan bimbingan, sehingga 2 perawat yang ditemukan berdasarkan penilaian ini bisa dibimbing dengan baik dengan memilah limbah dengan benar, Berdasarkan lembar observasi yang dilakukan tiga kali, mempunyai peniliaan yang signfikan karena hasil

pengamat/observer menilai bahwa seluruh perawat di IGD RSUD Dr. Soetomo sudah berperilaku benar dalam memilah limbah dengan benar, sehingga bisa dikatakan apa yang harapkan oleh pihak IGD RSUD Dr. Soetomo sudah sesuai harapan.

\section{Daftar Pustaka}

Adisasmito, W. 2007. Sistem Manajemen Rumah Sakit. Jakarta: PT. Raja Grafindo Persada.

Ali. 2005. Pengaruh Kualitas Pelayanan dan Peneraoan Prisipprinsipyang Sesuai. Jakarta

Chandra,

B.2007.Pengantar KesehatanLingkungan 
- Jakarta: Penerbit Buku KedokteranEGC. Darmadi, 2008.Tentang problematika dan pengendalian rumah sakit. Jakarta:

Penertbit Salemba Medika.

Departemen Kesehatan RI/ 1204/Menkes / 200

6.tentang Persyaratan Kesehatan Lingkungan Rumah Sakit. Jakarta: Depkes RI.

Ditjen P2MPL. 2004.

Kepmenkes RI Nomor: 1204/MENKES/SK/X /2004 tentang

Persyaratan

Kesehatan Lingkungan Rumah Sakit, Jakarta: Departemen

Kesehatan Republik Indonesia.

Keputusan Menteri

Kesehatan RI Nomor. 1204/Menkes/SK/X/ 2004.Pedoman

Keselamatan dan Kesehatan Kerja Puskesmas. Jakarta:

Kementerian

Kesehatan RI.

\section{Keputusan}

Menteri

Kesehatan

RI

Nomor.340/MENKES/

PER/III/2010 tentang klasifikasi rumah sakit.

Keputusan

Menteri

Kesehatan

RI
Bambang: Hubungan Pengetahuan $\mathrm{K} / \mathrm{XI} / 2010$ tentang Pedoman Organisasi Rumah Sakit Umum Pusat dan Rumah Sakit Daerah.

Madelan, 2003.Sistem Pengolahan Sampah. Instalasi Penerbitan PAM-SKL, Ujung Pandang.

Notoadmodjo.Soekidjo.200

7. Promosi Kesehatan dan Ilmu Perilaku. Jakarta: Rineke Cipta.

Peraturan Menteri

Kesehatan Republik Indonesia No. 56 Tahun 2014.Tentang Persyaratan

Kesehatan Lingkungan Rumah Sakit.

Prastowo, Andi. 2011 Memahami Metodemetode Penelitian. Depok, Sleman: ARRUZZ MEDIA.

Primadipta, Danny. 2014. Kualitas Pelayanan Pasien Instalasi Rawat Darurat (IRD) di RSUD Dr. Soetomo Surabaya. Skripsi Fakultas Ilmu Sosial dan Ilmu Politik. Universitas Jember.

Profil RSUD Dr. Soetomo Surabaya

Senja,R. 2008. Psikologi Pengajaran.Jakarta : PT. Gramedia Pustaka Utama.

Nomor.983/Menkes/S 
Soedjadi, R. 2006. Tentang Taksonomi Bloom. Surabaya: PPS Unesa

Sudjana, Nana.2010.

Tentang

Evaluasiproses dan hasilpembelajaran.

Jakarta: Bumi Aksara.

Suriasumantri,

2003.Filsafat Ilmu.

Sebuah Pengantar

Populer. Jakarta:

Pustaka Sinar

Harapan

Sugiyono, 2012.Metode Penelitian. Bandung:

Alfabeta.

Sunaryo, 2008.Psikologi untuk Keperawatan.

EGC: Buku

Kedokteran.

Tjandra Yoga Adhitama

dkk. 2006. Kesehatan

dan Keselamatan

Kerja, Jakarta: UI

PRESS. 